\title{
Perilaku Merokok Masyarakat Di Kecamatan Ciampea Kabupaten Bogor Jawa Barat
}

\section{Community Smoking Behaviour in Distric Ciampea Bogor, West Java}

\author{
Hidayati' ${ }^{1)}$ Bambang Setiaji ${ }^{2)}$ \\ 1)Program Studi Kesehatan Masyarakat, Fakultas Ilmu-Ilmu Kesehatan \\ Universitas Muhammadiyah Prof.Dr.Hamka \\ ${ }^{2)}$ Kementerian Kesehatan Republik Indonesia \\ Email: hidayati@uhamka.ac.id
}

\begin{abstract}
ABSTRAK
Pada tahun 2016, Provinsi Jawa Barat dipilih oleh Kementerian Kesehatan RI menjadi salah satu dari sembilan provinsi untuk program prioritas Indonesia Sehat dengan Pendekatan Keluarga (PIS-PK). Dari 12 indikator PIS-PK, indikator ke-9, yaitu anggota keluarga tidak ada yang merokok, merupakan indikator cakupan terendah di Kecamatan Ciampea Kabupaten Bogor Jawa Barat, yaitu sebesar 25,58\%. Melihat hal tersebut, penelitian ini dilakukan untuk menggali lebih dalam perilaku merokok di Kecamatan Ciampea. Penelitian ini menggunakan desain analisis kualitatif dan dilakukan pada bulan Oktober dan November 2016. Dengan cara purposive sampling, informan yang terpilih adalah 4 orang anggota rumah tangga (ART), 6 orang tokoh masyarakat, 5 orang kader kesehatan, 3 orang bidan desa, 2 orang petugas Puskesmas, dan 2 orang Kepala Puskesmas. Data dikumpulkan dengan metode wawancara mendalam dan diskusi kelompok terarah (Foccus Group Discussion/FGD). Analisis data dalam penelitian ini terdiri dari reduksi data, penyajian data, penyusunan kesimpulan. Merokok merupakan hal yang lumrah dilakukan di Kecamatan Ciampea. Sebagian besar dari mereka merupakan perokok sosial. Mereka merokok ketika sedang berkumpul dengan lingkungan sekitarnya. Walaupun demikian, mereka telah mengetahui bahwa terdapat peraturan terkait dengan larangan merokok.Warga Kecamatan Ciampea juga telah menyadari bahwa merokok memiliki dampak buruk bagi kesehatan seperti terserang penyakit terkait pernapasan. $\mathrm{Di}$ samping itu, mereka pun memahami bahwa merokok membawa pengaruh buruk bagi keadaan ekonomi mereka. Merokok merupakan kebiasaan sehari-hari warga di Kecamatan Ciampea walaupun mereka telah mengetahui larangan untuk merokok dan dampak buruknya.
\end{abstract}

Kata Kunci: Perilaku merokok, Regulation, Dampak, Ciampea

\section{ABSTRACT}

In 2016, West Java was selected by the Ministry of Health to become one of the nine provinces for the Healthy Indonesia priority program with the Family Approach (PIS-PK). Among 12 its indicators, the ninth indicator, smoking prohibition among famly member, is the lowest indicator in Ciampea sub-district, Bogor regency of West Java, which is $25.58 \%$. Hence, this study was conducted to explore the behavior of smoking in Ciampea District. The study had been done using qualitative design. This study was conducted in October - November 2016. Using purposive sampling, the informants were selectedas much as 4 household members (ART), 6 community leaders, 5 health care officer, 3 village midwife, 2 community health center officer, and 2 head of primary health care. Data was collected by in-depth interviews and focus group discussions (FGDs) and analyzed through data reduction, data presentation, and conclusion setting. Smoking is common in Ciampea District. Mostly, people in Ciampea are social smoker. They smoke when they in the social occasation. Nevertheless, they had knew there is regulation about smoking prohibition. They also had considered that smoking has bad impact in health such as respiratory disease. Beside that, they had noticed that smoking has negative influence in economic. Smoking is habitual behavior in Ciampea though they know its prohibited regulation and bad impact.

Keywords: Smoking Behavior, Regulation, Impact, Ciampea 
160 Hidayati, Bambang Setiaji Perilaku Merokok Masyarakat di Kecamatan Ciampea Kabupaten Bogor...

\section{PENDAHULUAN}

Konsumsi produk tembakau telah menjadi masalah global baik dari segi kesehatan, sosial, ekonomi, dan budaya. World Health Organization (WHO) memperkirakan kematian akibat rokom sebesar 8 juta pada tahun 2030 dan diperkirakan $80 \%$ kematian tersebut terjadi di negara berkembang. Selain itu, merokok menyebabkan berbagai macam penyakit seperti kanker, penyakit jantung, penyakit pembuluh darah, radang otak ,berbagai penyakit saluran pernafasan dan lain-lain.

Sebanyak $4,8 \%$ dari 1,3 miliar perokok dunia ada di Indonesia. Sebesar $71 \%$ rumah tangga di Indonesia mempunyai sedikitnya satu orang perokok, dan $84 \%$ diantaranya merokok didalam rumah (Perkumpulan Promotor dan Pendidik Kesehatan Masyarakat Indonesia, 2015). Berdasarkan nilai Indeks Pembangunan Kesehatan Masyarakat (IPKM), perilaku merokok terbanyak terdapat di Provinsi Jawa Barat dengan nilai 32,70 jika dibandingkan nilai IPKM nasional yaitu 29,31.

Di samping itu, perilaku merokok juga masuk kedalam indikator keluarga sehat dalam program Indonesia Sehat melalui Pendekatan Keluarga (PIS-PK) yaitu indikator anggota keluarga tidak ada yang merokok. Program PIS-PK merupakan pendekatan pelayanan kesehatan yang berkesinambungan (continuum of care) dilakukan terhadap seluruh tahapan siklus hidup manusia (life cycle), sejak masih dalam kandungan sampai menjadi lansia. Oleh karena itu, fokus pelayanan kesehatan harus pada keluarga. Individu-individu harus dilihat sebagai bagian dari keluarganya. Kesehatan keluarga diukur keberhasilannya melalui Indeks Keluarga Sehat atau IKS (Kementerian Kesehatan Republik Indonesia, 2016).

Berdasarkan penelitian yang dilakukan sebelumnya di Kecamatan Ciampea, indikator keluarga sehat kesembilan, anggota keluarga tidak ada yang merokok, merupakan indikator dengan cakupan paling rendah, yaitu 25,58\%. Bahkan disalah satu desa, Desa Ciampea Udik, seluruh anggota keluarga yang layak menjadi sampel pada penelitian ini merupakan perokok. Oleh karena itu, penelitian ini dilakukan untuk menggali lebih dalam perilaku merokok di Kecamatan Ciampea.

\section{SUBYEK DAN METODE}

Penelitian ini merupakan penelitian analisis kualitatif. Penelitian ini dilakukan pada bulan Oktober dan November 2016. Pemilihan informan dalam penelitian ini mengacu kepada prinsip kesesuaian (appropriatenes) dan kecukupan (adequency) (Meleong, 2014).

Informan dipilih dengan cara purposive sampling dari empat desa yang ada di Kecamatan Ciampea, yaitu Desa Bojong Rangkas (BR), Desa Tegal Waru (TW), Desa Cinangka (CN) dan Desa Ciampea Udik (CU). Dengan demikian, Informan pada penelitian ini adalah anggota rumah tangga (ART) sebanyak 4 orang, tokoh masyarakat sebanyak 6 orang, kader kesehatan sebanyak 5 orang,bidan desa sebanyak 3 orang, petugas puskesmas sebanyak 2 orang, kepala puskesmas sebanyak 2 orang.

Teknik yang digunakan adalah wawancara mendalam dan diskusi kelompok terarah (Focus Group Discussion/FGD). Instrumen Penelitian yang digunakan adalah peneliti sendiri, pedoman wawancara, catatan lapangan, alat rekam suara dan gambar (foto) yang diambil dari smartphone dan alat tulis.

Proses pengolahan data dilakukan melalui tahapan transkripsi, pengorganisasian data, pengkodean, dan reduksi data. Penyajian data dalam bentuk teks naratif dan penarikan kesimpulan untuk mencari alur sebab akibat, pola-pola, penjelasan dan proporsi yang dibuat dalam satu kesimpulan.

\section{HASIL}

Hasil penelitian mengungkapkan perilaku merokok dilakukan oleh anggota keluarga berjenis kelamin laki-laki dan wanita dengan rentang usia 10-61 tahun terdapat pada Tabel 1.

Hasil penelitian mengemukakan bahwa perilaku merokok merupakan perilaku yang biasa ditemui di kecamatan Ciampea. Di samping itu, perilaku merokok di Kecamatan Ciampea juga didasari karena faktor budaya. Kegiatan sosial di masyarakat merupakan pemicu perilaku tersebut.

“merokok... yah itu mah kelakuan biasa Teh buat orang laki, malah ada juga perempuan “( $M, \operatorname{Pr}, 19$ tahun $)$

“Kalau merokok hmm... rasanya sulit yah karena sudah masuk faktor budaya, disini kalau kumpul-kumpul atau ada kegiatan 
Tabel 1. Karakteristik Informan

\begin{tabular}{|c|c|c|c|c|}
\hline No & Informan & Jenis Kelamin & Umur & Keterangan \\
\hline 1 & Informan E & Perempuan & 50 tahun & Informan Kunci \\
\hline 2 & Informan $\mathrm{N}$ & Perempuan & 45 tahun & Toma (Ketua RW) Desa Bojong Rangkas (BR) \\
\hline 3 & Informan $\mathrm{H}$ & Perempuan & 50 tahun & Toma (Kader Kes) Desa BR \\
\hline 4 & Informan A & Perempuan & 30 tahun & Bidan Desa BR \\
\hline 5 & Informan F & Perempuan & 33 tahun & Informan Kunci \\
\hline 6 & Informan L & Perempuan & 32 tahun & Kader Kes Desa Tegal Waru (TW) \\
\hline 7 & Informan As & Laki-laki & 45 tahun & Toma (Ketua RW Desa TW) \\
\hline 8 & Informan $\mathbf{M}$ & Perempuan & 19 tahun & Informan Kunci \\
\hline 9 & Informan Id & Perempuan & 32 tahun & Kader Kes Desa Cinangka (CN) \\
\hline 10 & Informan Ns & Laki-laki & 51 tahun & Toma Desa CN (ketua RT) \\
\hline 11 & Informan Iy & Laki-Laki & 61 tahun & Toma Desa CN (ketua RW) \\
\hline 12 & Informan $\mathrm{Nr}$ & Laki-Laki & 43 tahun & Toma Desa CN (Ka Des) \\
\hline 13 & Informan $\mathrm{Er}$ & Perempuan & 50 tahun & Bidan Desa CN \\
\hline 14 & Informan $\mathbf{R}$ & Perempuan & 24 tahun & Informan Kunci \\
\hline 15 & Informan Ln & Perempuan & 35 tahun & Kader Kes Desa Ciampea Udik (CU) \\
\hline 16 & Informan Es & Perempuan & 25 tahun & Toma Desa CU (Ketua RW) \\
\hline 17 & Informan Uc & Perempuan & 43 tahun & Bidan Desa CU \\
\hline 18 & Informan Un & Laki-Laki & 45 tahun & Kepala UPT PKM Ciampea \\
\hline 19 & Informan $\mathrm{Li}$ & Perempuan & 30 tahun & Petugas Promkes UPT PKM Ciampea \\
\hline 20 & Informan $\mathrm{S}$ & Laki-laki & 35 tahun & Kepala UPF PKM Ciampea Udik \\
\hline 21 & Informan $\mathrm{Ij}$ & Perempuan & 28 tahun & Kader Desa CU \\
\hline
\end{tabular}

hajatan kadang-kadang ngundang pakai rokok., ngerokok juga dicontohin sama bapaknnya, yang dicontohin lebih cepet dilakuin"(Er, Pr, Bidan Desa)

Walaupun demikian, mereka menyadari bahwa hal tersebut tidak patut dilakukan. Ketidakpatutan tersebut dikaitkan dengan hukum agama Islam.

"kalau menurut saya mah itu perilaku yang tidak bagus.. dalam agama saja sudah ada hukumnya makruh bahkan klo nggak salah Muhammadiyah mengharamkan deh...betul gitu yah Neng...ga terlalu apal saya...cuma yang saya ketahui merokok itu sebenarnya merugikan karena sebenarnya ngisep racun."(E, Pr, 50 Tahun )

Walaupun banyak yang mengkonsumsi rokok, peraturan terkait dengan rokok telah dibuat di daerah Ciampea. Salah satunya adalah aturan KTR (Kawasan Tanpa Rokok).

"Saya mah ngehormati aja yang ngerokok, soalnya itu hak asasi seseorang, saya ga ngerokok ,..........kaya ditempat-tempat umum kalau ada aturannya juga ada KTR diikutin aja sekarang kan ada tulisan smoking area dan non smoking area", (A, Lk, Toma)

Di daerah tersebut, peraturan merokok sebagai bagian dari Perilaku Hidup Bersih dan Sehat (PHBS).

"kayanya pernah tapi ga tahu pasti siapa yang ngeluarin dulu juga ada informasi dari kader tentang naon teya(apa itu)Teh (Kak) namanya? Nah itu..tuh PHBS ..kudu kumaha (harus gimana) dirumah, ga ngerokok, makan sayur, pokokna ma kitu lah kudu hidup sehat" (R, Pr,24 tahun)

Hasil studi juga mengemukakan bahwa rokok menimbulkan dampak kesehatan. Salah satu contohnya adalah timbulnya penyakit TB Paru yang biasa dikenal dengan nama flek.

"Nah eta.... asepna bikin flek (nah itu... asepnya bikin flek)” (E, Pr, Kader Kesehatan)

Selain itu, perilaku merokok juga berdampak pada kondisi ekonomi. Hasil penelitian mengemukakan bahwa sebagian besar pendapatan digunakan untuk membeli rokok. 
162 Hidayati, Bambang Setiaji Perilaku Merokok Masyarakat di Kecamatan Ciampea Kabupaten Bogor...

“ merokok selain ga sehat tambahannya bikin kanker Teh..., kantong" $(F$, Pr, 33 tahun)

\section{DISKUSI}

Pengetahuan dan sikap masyarakat Ciampea terkait rokok dan dampaknya tidak sejalan dengan perilaku. Seharusnya, menurut Notoatmodjo, pengetahuan akan dapat mempermudah seseorang untuk berperilaku. Apabila suatu penerimaan perilaku baru didasari oleh pengetahuan, kesadaran dan sikap positif maka perilaku tersebut akan bersifat lama (Notoatmodjo, 2010).

Rokok oleh sebagian penduduk di Kecamatan Ciampea juga digunakan sebagai pengganti surat undangan untuk menghadiri keriaan atau acara-acara penting dalam suatu keluarga. Semakin berkemampuan maka jumlah maupun jenis dan merek rokok yang digunakan lebih bagus dan mahal. Kebiasaan ini tidak tertulis secara formal dan terus berkembang di dalam masyarakat. Seolah-olah menjadi bagian dari budaya setempat.

Peranan Keluarga dalam perilaku merokok masyarakat di Kecamatan merupakan peran interrelasi sosial yang berfungsi sebagai hasil dari pembentukan norma tingkah laku dan meneruskan nilai-nilai budaya. Sebagian besar perokok berdasarkan wawancara mendalam mendapatkan pengetahuan merokok dan contoh perilaku yang biasanya diturunkan dari anggota keluarga lainnya, seperti kakek atau ayah.

Hasil penelitian juga menunjukkan bahwa perilaku merokok berdampak negatif pada kondisi ekonomi. Hasil Survei Lembaga Demografi Fakultas Ekonomi Universitas Indonesia, menemukan besarnya pengeluaran untuk rokok adalah Rp 3.545 per hari atau Rp 106.350 per bulan. Ini setara dengan $26 \%$ penghasilan buruh tani tembakau per bulan. Dengan kata lain, seperempat upah buruh habis untuk dibakar. Harga satu bungkus rokok merek terkenal setara dengan setengah $\mathrm{kg}$ telur, $2 \mathrm{~kg}$ beras, 1 liter minyak goreng dan lainnya. Jadi sebenarnya orang miskin bisa membeli makanan bergizi jika tidak membeli rokok. Selain meningkatkan risiko sakit akibat rokok yang memperburuk kemiskinan, risiko anak-anak menderita kekurangan gizi juga tinggi karena anggaran untuk membeli makanan dialihkan untuk membeli rokok (Widiati, 2013).

Perilaku merokok di Kecamatan Ciampea harus dapat diprioritaskan sebagai program berbasis pemberdayaan masyarakat, agar dapat dirasakan sebagai masalah bersama sehingga dapat ditemukan upaya-upaya mengatasinya. Peran dan dukungan seluruh pihak amat diperlukan, Puskesmas sebagai pelaksana program PIS-PK menggerakkan dan bertanggungjawab terhadap pembangunan kesehatan diwilayah kerjanya. Puskesmas bertugas untuk melaksanakan pembangunan kesehatan guna mewujudkan kecamatan sehat, yaitu yang mempraktikkan perilaku hidup bersih dan sehat, yang meliputi kesadaran, kemauan dan kemampuan untuk hidup sehat dari masyarakat yang berada di wilayah kerjanya.

\section{KESIMPULAN}

Hasil penelitian ini menyimpulkan bahwa cakupan Indikator PIS-PK ke-9 dipengaruhi bagi masyarakat Kecamatan Ciampea, perilaku merokok merupakan suatu tindakan yang lumrah Walaupun demikian, mereka tahu tindakan tersebut tidak patut dilakukan dan terdapat peraturan terkait dengan larangan merokok. Selain itu, mereka sadar bahwa merokok mempunyai dampak negatif bagi kesehatan dan ekonomi mereka. Oleh karena itu, perilaku merokok harus dirasakan sebagai masalah kesehatan bersama utamanya dengan adanya program PISPK. Kedekatan Puskesmas dengan masyarakat dan keluarga harus dapat lebih dijalin dan ditingkatkan melalui upaya promosi kesehatan dengan intervensi pendekatan budaya.

\section{UCAPAN TERIMAKASIH}

Ucapan terimakasih untuk seluruh masyarakat di Kecamatan Ciampea, Pihak Kecamatan dan UPT. Kesehatan Kecamatan dan UPF Kesehatan Desa Cinangka, UPF Kesehatan Desa Ciampea Udik, dan Puskesmas Keliling Desa Tegal Waru, Para Bidan Desa, Tokoh masyarakat dan Kader Kesehatan. 


\section{DAFTAR PUSTAKA}

Komisi Nasional Perlindungan Anak dan Worl Health Organization. (2008). Denormalisasi Industri Rokok, Toolkit untuk Remaja. Jakarta: Komisi Nasional Perlindungan Anak.

Perkumpulan Promotor dan Pendidik Kesehatan Masyarakat Indonesia. (2015). Modul Pelatihan Pendidik Sebaya "Generasi Sehat Tanpa Rokok". Jakarta: Perkumpulan Promotor dan Pendidik Kesehatan Masyarakat Indonesia.

Kementerian Kesehatan Republik Indonesia. (2016). Petunjuk Teknis Penguatan Manajemen Puskesmas Dengan Pendekatan Keluarga. Jakarta: Kementerian Kesehatan Republik Indonesia.

Meleong, L. (2014). Meodologi Penelitian Kualitatif. edisi revisi. Bandung: Remaja Rosdakarya

Widiati,S. (2013). Efektifitas Pesan Bahaya Rokok Pada Bungkus Terhadap Perilaku Merokok Masyarakat Miskin. Jurnal Promkes, Vol. 1, No. 2 Desember 2013: $105-110$

Notoatmodjo, S. (2010). Ilmu Perilaku. Jakarta: Rieneka Cipta. 